\title{
The Commission on European Family Law (CEFL) and its Principles of European Family Law Regarding Parental Responsibilities"
}

\author{
Katharina Boele-Woelki · Dieter Martiny
}

Published online: 27 March 2007

(C) ERA 2007

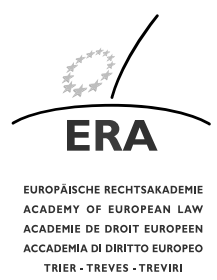

\begin{abstract}
The Principles of European Family Law which are drafted by the Commission on European Family Law (CEFL) have recently been supplemented by the Principles Regarding Parental Responsibilities. In drafting Principles of European Family Law the CEFL aims to contribute to the harmonisation of family law in Europe. They may be used as a frame of reference. The first set of Principles in the field of Divorce and Maintenance Between Former Spouses was launched in 2004. In its new Principles the CEFL has developed a comprehensive and original set of rules in the field of parental responsibilities.
\end{abstract}

Keywords CEFL $\cdot$ harmonisation of family law $\cdot$ parental responsibilities $\cdot$ rights of the child $\cdot$ best interest of the child

\section{The CEFL}

During the last five years or so family law has gradually achieved a prominent position on the agenda addressing the harmonisation of private law in Europe. The CEFL,

\footnotetext{
Prof. Dr. Katharina Boele-Woelki

University of Utrecht, Molengraaff Instituut voor Privaatrecht

Nobelstraat 2a, 3512 EN Utrecht, The Netherlands

e-mail: k.boele@law.uu.nl

Prof. Dr. Dieter Martiny

Europa Universität Viadrina, Lehrstuhl für Bürgerliches Recht, IPR und Rechtsvergleichung Große Scharrnstraße 59, 15230 Frankfurt/Oder, Deutschland

e-mail: martiny@euv.frankfurt-o.de
}

\footnotetext{
* This article is based on the presentation given by Katharina Boele-Woelki at the ERA conference "Current Developments in European Family Law and the Law of Succession" held in Trier on 25-26 September 2006.
} 
which was established in 2001, contributes to the harmonisation debate as regards its desirability and feasibility through the drafting of Principles of European Family Law. Twenty-eight experts in the field of comparative family law from twenty-two European jurisdictions are taking part in the activities of the CEFL. ${ }^{1}$ Its Principles are based on comprehensive comparative research. In respect of the adopted results, the CEFL considers it to be one of its main tasks to reveal the criteria upon which the choices are based. As a result, a great deal of consideration has been given to the explanation as to why a certain Principle has been adopted. These commentaries provide a guide to the policy considerations behind the choices. They are in a sense the dominant features of the drafters, suggesting which is "the best", the more "functional" or the more "efficient" rule. In this process, both the common core method and the better law approach were applied. As a result, CEFL Principles may serve as a frame of reference and a source of inspiration for legislatures in their quest to modernise their family laws.

To date, two sets of Principles are available. The first set was published in 2004. It addresses divorce (Part 1) and maintenance between former spouses (Part 2). ${ }^{2}$ The recently finalised second set in the field of parental responsibilities (Part 3) is the main focus of this contribution. The Principles on matrimonial property law (Part 4) are to be expected in 2009/2010.

CEFL's working language is English. Only the black-letter text of the Principles is formulated in English, French and German. These different versions are equally authentic. A Dutch, Spanish and Swedish translation has been added to the respective publications.

The CEFL does not limit itself to the drafting of common principles but also organises family law conferences on a regular basis in order to present its results in a broader academic forum. ${ }^{3}$

\section{The Principles of European Family Law Regarding Parental Responsibilities}

In the field of parental responsibilities the same working method has been followed as with regard to the Divorce and Maintenance Principles. ${ }^{4}$ On the basis of a detailed questionnaire containing 62 questions the experts prepared twenty-two comprehensive national reports based on the law as it stood in 2004. These national reports, together with the relevant legal provisions, are available on CEFL's website. ${ }^{5}$ In addition, an integrated version of all the reports has been published. ${ }^{6}$ On the basis of

\footnotetext{
1) For more information on the background to the CEFL, its organisation, experts and publications, see www.law.uu.nl/priv/cefl.

2) Boele-Woelki/Ferrand/González Beilfuss/Jänterä-Jareborg/Lowe/Martiny/Pintens [3].

3) The proceedings of the first two conferences which took place in Utrecht, the Netherlands, in 2002 and 2004 are published in the European Family Law series (www.intersentia.be) which was established by CEFL's Organising Committee in 2003. The third conference on European Challenges in Contemporary Family Law will take place in Oslo from $7^{\text {th }}-9^{\text {th }}$ June 2007. It is organised in collaboration with the Department of Private Law of the University of Oslo in Norway.

4) Boele-Woelki [1].

5) See note 1 .

6) Boele-Woelki/Braat/Curry-Sumner [2].
} 
this comparative material the CEFL formulated 39 Principles classified into eight chapters. ${ }^{7}$

Due to the fact that in the field of parental responsibilities many international and European instruments are to be taken into account, the structure and content of the Principles regarding Parental Responsibilities is to some extent different to the structure of CEFL's first Principles. Each section containing a Principle consists of four parts. The text of the Principle itself (1) is followed by an overview of the relevant international and/or European provisions regarding the issue addressed in the Principle (2) in order to recall the international commitments that have previously been achieved. The international obligations build the framework along which the Principles have been drafted. The comparative overviews (3) and the comments (4) do not only refer to the twenty-two national reports, but include, in addition, the related international and/or European instruments. All four parts belong together. They are part and parcel of the Principles as a whole.

The whole set of rules is preceded by a Preamble which includes both generally acknowledged considerations and commonly felt desires with regard to the situation of family law in Europe as well as the notion of the child's rights and welfare which served as the main guideline in the drafting process. The Preamble also refers to the free movement of persons which is a core principle of the European Union. It has gradually gained more significance in the discussion about the unification of private international law in family matters ${ }^{8}$ as well as the harmonisation of substantive family law.

\subsection{Definitions}

What are parental responsibilities and who are its holders? Two definitions are provided in the first Chapter. In accordance with international and European instruments the CEFL opted for a broad concept of parental responsibilities consisting of a collection of rights and duties that concerns the taking care of the child's person and properties (Principle 3:1). Concepts like guardianship and custody that are still used in national systems have been abandoned. CEFL's concept of parental responsibilities applies to children from the moment of their birth until they have reached majority. A difference between younger and adolescent children has been recognised, though the indication of an age limit has intentionally not been provided. It not only depends on the child's age but also upon his/her maturity whether his/her opinion should be taken into account.

The Principles refer to the rather long-winded term "holders of parental responsibilities". Normally, the child has two parents who are the holders of parental responsibilities. However, a person other than a parent, who has no legal ties with the child, can also be attributed with and exercise parental responsibilities. Principle 3:2 clarifies this distinction. Primarily, the parents are in charge of the exercise of parental responsibilities. However, physical persons other than the parents as well as public bodies can also have parental responsibilities. According to the CEFL Principles it

\footnotetext{
7) Boele-Woelki/Ferrand/González Beilfuss/Jänterä-Jareborg/Lowe/Martiny/Pintens [4].

8) Meeusen/Pertegás/Straetmans/Swennen [6].
} 
is thus possible that there might be even more than two holders of parental responsibilities.

\subsection{Rights of the child}

The relevant international and European human rights instruments have profoundly marked Chapter II, which is devoted to the rights of the child. With its five Principles this Chapter forms the main general part of the CEFL Principles. ${ }^{9}$ The rights of the child are always to be taken into account in all matters of parental responsibilities. They constitute the principal point of departure along which all other issues should be addressed.

Principle 3:3 considers the best interests of the child as the primary consideration. It should be the ultimate, decisive reflection. The assessment of the child's best interests should always be made from the child's perspective, regard being had to his or her present and future interests and needs. It will not come as a surprise that the CEFL also leaves the content of the "best interests of the child" undefined, as do the various international instruments and all of the national jurisdictions surveyed. The "best interests of the child" is a changing notion, dependent not only on the prevailing values in the society in question as regards children, but also on the individual child and his or her present situation (age, maturity, personality, needs, abilities, health, etc.). Indirectly, its content is developed in all the following Principles, as these aim to materialise what constitutes the child's best interests in different kinds of situations.

Principle 3:4 explicitly recognises the child's autonomy. Children are young by definition, generally inexperienced and vulnerable, which justifies limitations to their right to self-determination. International instruments and national laws refer to the child's age and maturity as relevant criteria whereas Principle 3:4 emphasises the link between the child's developing ability and his or her increasing need to act independently. The idea behind this is that a person's age should not as such be decisive for his or her autonomy, but that autonomy requires a certain capacity. The more able the child, the greater is his or her need to act independently. Ability, in turn, is dependent on the child's maturity.

Children should not be discriminated against on grounds such as sex, race, colour, language, religion, political or other opinion, national, ethnic or social origin, sexual orientation, disability, property, birth or other status, irrespective of whether these grounds refer to the child or to the holders of parental responsibilities (Principle 3:5). This list is only indicative. Other grounds than the ones explicitly mentioned may also constitute forbidden discrimination. Furthermore, the unequal treatment of children on grounds such as the status of the child's residence should be prohibited. Children who reside illegally in a country should enjoy the same rights, for example in respect of the right to medical care and education, as are enjoyed by the children legally resident in that country. Only then can the holders of parental responsibilities exercise their rights and duties on an equal footing with others.

Since the adoption and entry into force of the Convention on the Rights of the Child, the child's right to be heard has become well established in different parts of the world. The child's right to be heard not only when a competent authority takes a

\footnotetext{
9) Also Chapter I (Definitions) and Chapter VIII (Procedure) are of a more general nature.
} 
decision, but also outside of proceedings in situations where the holders of parental responsibilities make agreements or take decisions concerning the child has been acknowledged in Principle 3:6. This is an obligatory point of departure. It applies not only to the assessment regarding whether the child should be informed, consulted and given the opportunity to express his or her opinion, but also to what weight should be given to the views expressed by the child. In the latter respect the child's capability of forming his or her own views is, implicitly, of relevance. Unlike several national systems, ${ }^{10}$ Principle 3:6 does not determine any special age or degree of maturity. The older and more mature the child, the greater is the weight to be attached to the views expressed by that child.

A clash of interests between the child's interests and those of a holder of parental responsibilities may occur in many different types of situations and that is why Principle 3:7 states that, in the case of conflict, which should also include any risk of conflict, the child's interests should be protected. The manner in which the protection should take place depends on the situation and the issue at hand. One means is by appointing a special representative for the child. Other solutions include the discharge of parental responsibilities, limitations to the right of contact with the child or appointing an additional holder of parental responsibilities to exercise these responsibilities.

\subsection{Parents and third persons}

The next issue to be decided is who is attributed with parental responsibilities. Therefore Chapter III of the Principles deals with the parental responsibilities of parents and third persons. In almost all cases the child has two holders of parental responsibilities who are at the same time his/her parents. Therefore, parents whose legal parentage has been established should have parental responsibilities for the child (Principle 3:8). Parentage as such is not dealt with in the CEFL Principles.

Parental responsibilities generally mean joint responsibilities. If the parents are married, this is in line with the generally accepted rule that parents have ipso iure joint custody. ${ }^{11}$ However, if the parents are not married, in some legal systems the basic rule is still that the mother has sole parental responsibilities; the father can obtain parental responsibilities only under certain conditions. ${ }^{12}$ For instance, according to German law both parents of a child born out of wedlock have to issue a declaration of parental responsibility. ${ }^{13}$ The CEFL Principles instead follow the trend that also in these cases there should be joint parental responsibilities. ${ }^{14}$ The reason for this is equal treatment of the parents irrespective of their gender. If the father is unsuitable to exercise parental responsibilities there must be a decision to this effect by the competent authority.

\footnotetext{
10) E.g. Norway (7 years), Bulgaria (10 years), Denmark and The Netherlands (12 years). Cf. Boele-Woelki/Braat/Curry-Sumner [2], p. $773 \mathrm{ff}$.

${ }^{11)}$ Boele-Woelki/Braat/Curry-Sumner [2], p. $265 \mathrm{ff}$.

12) Boele-Woelki/Braat/Curry-Sumner [2], p. $339 \mathrm{ff}$.

13) § 1626a German Civil Code. Cf. Dethloff [5], p. 318.

${ }^{14)}$ E.g. Art. 372 French Civil Code, Art. 317bis Italian Civil Code. Cf. Boele-Woelki/Braat/Curry-Sumner [2], p. $339 \mathrm{ff}$.
} 
However, under certain circumstances a third person who has no legal ties with the child can also be attributed with and exercise parental responsibilities, e.g. the parent's partner. Parental responsibilities may in whole or in part also be attributed to such a person (Principle 3:9). Since different factual situations exist the CEFL Principles leave it open as to how and on what conditions such an attribution takes place. According to the Principles it is also possible that there might be even more than two holders of parental responsibilities.

The effect of a separation or the dissolution of a marriage on parental responsibilities is dealt with separately. Today, national family laws recognise that parental responsibilities are a consequence of parenthood and not of marital status; therefore joint custody is generally maintained without a court decision despite a divorce or separation between the parents. ${ }^{15}$ Under the Principles parental responsibilities should likewise be affected neither by the dissolution or annulment of the marriage or other formal relationship nor by a legal or factual separation (Principle 3:10).

\subsection{Exercising Parental Responsibilities}

Chapter IV of the Principles is devoted to the exercise of parental responsibilities. Although it is not always easy to make a clear distinction between the allocation of parental responsibilities and the mere exercise thereof, two different terms have been used. Issues concerning such exercise are to be solved only if questions on the use of parental powers and/or performance of the duties by the holders of parental responsibilities arise. Chapter IV contains two sections, making a distinction between joint exercise, which is the basic rule, and sole exercise.

Section A concentrates on parents. Parents having parental responsibilities should have an equal right and duty to exercise such responsibilities and whenever possible they should exercise them jointly (Principle 3:11). However, for practical reasons it is necessary to empower one parent to act alone in some situations. This is already necessary when the parents live together and it is inevitable if the parents live apart. Therefore the Principles deal with daily matters, important and urgent decisions. Parents with joint parental responsibilities have the right to act alone with respect to daily matters (Principle 3:12 (1)).

The Principles, however, also define an area where a joint decision by the parents is necessary. Important decisions concerning matters such as education, medical treatment, the child's residence or the administration of his or her property should be taken jointly (Principle 3:12 (1)). The third group are urgent cases. For example, in the case of an accident, a parent should have the right to act alone. The other parent should be informed without undue delay (Principle 3:12 (2)).

Since there is, in general, a joint exercise of parental responsibilities by the parents an informal agreement on this exercise should be the norm. Subject to the best interests of the child, parents having joint parental responsibilities may agree on the exercise of parental responsibilities (Principle 3:13 (1)). The agreement between the parents will generally be informal. However, there can also be a formal agreement and the competent authority may scrutinise the agreement (Principle 3:13 (2)).

${ }^{15)}$ Boele-Woelki/Braat/Curry-Sumner [2], p. 275 ff. and Patti [7]. 
If there is a disagreement between parents having joint parental responsibilities on the exercise of such responsibilities, this conflict has to be resolved in the best interest of the child. The parents or one parent alone may apply to the competent authority (Principle 3:14 (1)). For these cases the Principles also stress the advantages of an agreement between the parents which should be promoted by the competent authority (Principle 3:14 (2)). Where such an agreement cannot be reached, the competent authority may divide the exercise of parental responsibilities between the parents but can also decide on the dispute itself (Principle 3:14 (3)). In this respect the Principles do not follow the more restrictive approach of some jurisdictions which only allow an empowerment of one of the parents. ${ }^{16}$

If only one parent has parental responsibilities this means that he or she should exercise them alone (Principle 3:16). According to Principle 3:15 sole exercise upon agreement or decision is possible. Subject to the best interests of the child a parent may exercise parental responsibilities alone upon agreement between the parents according to Principle 3:13. Exercise by one parent is also possible by a decision of the competent authority.

Section B deals with third persons. Principle 3:17 allows the exercise of such responsibilities in addition to or instead of the parents. A person other than a parent may exercise some or all parental responsibilities in addition to or instead of the parents. Special cases where a third person can act by law are decisions in daily matters. The parents' partner living with the child may take part in decisions with respect to daily matters unless the other parent having parental responsibilities objects to this (Principle 3:18).

2.5 Content: the child's person and property and maintenance of personal relationships

Chapter V of the Principles deals with the content of parental responsibilities and is divided into two sections. Section A addresses the child's person and property and deals with different issues separately. In accordance with the traditional concept of custody Principle 3:19 (1) guarantees, in the first place, care, protection and education. The holders of parental responsibilities should provide the child with these in accordance with the child's distinctive character and developmental needs. Under no circumstances should the child be subjected to corporal punishment or any other humiliating treatment (Principle 3:19 (2)). This is in accordance with the vast majority of national laws. ${ }^{17}$

Although in many legal systems the care of the child includes the determination of his or her place of residence, ${ }^{18}$ a separate provision in the Principles deals with the residence of the child. If parental responsibilities are exercised jointly the holders of parental responsibilities who are living apart should agree with whom the child resides (Principle 3:20 (1)). Since alternating residence is on the one hand a modern

\footnotetext{
16) E.g. $\$ 1628$ German Civil Code.

${ }^{17)}$ Boele-Woelki/Braat/Curry-Sumner [2], p. $131 \mathrm{ff}$.

${ }^{18)}$ E.g., $\$ 1631$ para. 1 German Civil Code.
} 
trend in recent legislation, ${ }^{19}$ but is sometimes also a controversial issue, ${ }^{20}$ it seemed appropriate to deal with the matter in the Principles. According to Principle 3:20 (2) the child may reside on an alternating basis with the holders of parental responsibilities upon either an agreement approved by a competent authority or a decision by a competent authority. The competent authority should take into consideration several factors such as the age and opinion of the child. The ability and willingness of the holders of parental responsibilities to cooperate with each other in matters concerning the child, as well as their personal situation, is also important. Last but not least, the distance between the residences of the holders of parental responsibilities and to the child's school has to be taken into account.

Another often hotly debated issue is the relocation of the child. In some systems the residential parent is free to relocate with the child even without the other parent's consent. This unilateral power of relocation is sometimes restricted to relocation within the jurisdiction. In some of these systems parental responsibility holders can agree to subject relocation to mutual consent. ${ }^{21}$ In others the courts can decide to limit this unilateral power of relocation. ${ }^{22}$ There are often more restrictions available to so-called external relocation, that is relocation implying leaving the jurisdiction, than there are to internal relocation. In other systems a change to the child's residence always requires the consent of both parents. If one of the holders of parental responsibilities does not consent, the competent authority will decide on the relocation. CEFL nevertheless decided to introduce a Principle specifically dealing with relocation in order to respond to ever increasing mobility in European society. Principle 3:21(3) contains a non-exhaustive list of factors which have to be taken into consideration by the competent authority in order to take a decision on relocation. The competent authority has to find a balance between the right of the child to maintain personal relationships with the non-residential parent and close relatives and persons with whom the child has a close relationship (Principle 3:25) and the right of the residential parent to move in pursuit of a valid purpose, in order, for example, to improve his or her professional situation or to follow a new partner (free movement rights). Geographical distance and accessibility as well as the personal, particularly the financial, situation of the holders of parental responsibilities are crucial factors. As always, due weight should be given to the child's opinion, having regard to his or her age and maturity (Principle 3:6).

There are several legal approaches to the administration and disposal of the child's property. The common law approach is that the administration of property is not a part of the power of the parents whereas in the Nordic countries this is seen as a question of guardianship. ${ }^{23}$ The Principles follow the dominating central European approach according to which parental administration is a consequence of custody. ${ }^{24}$ Since the administration of the child's property is treated by the Principles as a part of parental responsibilities, some provisions deal with important details. The basic rule

\footnotetext{
${ }^{19)}$ E.g., Art. 373-2-9 French Civil Code establishing this as a rule. Cf. Boele-Woelki/Braat/Curry-Sumner [2], p. $547 \mathrm{f}$.

20) Boele-Woelki/Braat/Curry-Sumner [2], p. $545 \mathrm{ff}$.

${ }^{21)}$ E.g. Spain. Cf. Boele-Woelki/Braat/Curry-Sumner [2], p. 541.

${ }^{22)}$ E.g. England and Wales. Cf. Boele-Woelki/Braat/Curry-Sumner [2], p. $535 \mathrm{f}$.

${ }^{23)}$ Stoljar [10], sec. 206; Boele-Woelki/Braat/Curry-Sumner [2], p. $19 \mathrm{ff}$.

${ }^{24)}$ E.g. $\$ 1626$ German Civil Code. Cf. Boele-Woelki/Braat/Curry-Sumner [2], p. $201 \mathrm{ff}$.
} 
is that the holders of parental responsibilities should administer the child's property with due care and diligence in order to preserve and, where possible, to increase the value of the property (Principle 3:22 (1)). However, the Principles do not go into detail. For effective control national procedural rules and institutions are necessary.

In administering the child's property the holders of parental responsibilities should not make gifts unless the gifts are deemed to be made under a moral obligation (Principle 3:22 (2)). The income derived from the child's property which is not needed for the proper management of the property and for the maintenance and education of the child may, where necessary, be used for the needs of the family (Principle 3:22 (3)).

The power of the holders of parental responsibilities is not unrestricted. The holders of parental responsibilities should not administer property acquired by a child through a testamentary disposition or a gift, if the testator or the donor has so instructed (Principle 3:23 (1)).

Similarly the earnings of the child should not be administered by the holders of parental responsibilities unless the child is not of sufficient age and maturity to decide himself or herself (Principle 3:23 (2)). This seems to be an appropriate solution between the approaches of absolute freedom of disposal and binding parental restrictions. Where transactions can have significant financial consequences for the child the authorisation of the competent authority should be necessary (Principle 3:23 (3)). This includes transactions such as the disposal of land or taking out a loan on behalf of the child. However, due to the diversity of the national laws of contracts and property, a universally applicable list of transactions cannot be given.

Another part of parental responsibilities is legal representation which is dealt with separately in the Principles. The holders of parental responsibilities should legally represent the child in matters concerning the child's person or property (Principle 3:24 (1)). Restrictions are also necessary in this field. Legal representation should not take place under circumstances where there is a conflict of interest between the child and the holders of parental responsibilities (Principle 3:24 (2)). This can be the case in legal transactions with particularly close relatives of the holder of parental responsibilities representing the child. Having regard to the child's age and maturity, the child should have the right to self-representation in legal proceedings concerning himself or herself (Principle 3:24 (3)).

In Section B the importance of the maintenance of personal relationships, particularly with the non-residential parent, is recognised. The Principles prefer the notion of "contact" which is also used in the European Contact Convention ${ }^{25}$ to "access" in the Brussels II bis Regulation. ${ }^{26}$ The content of contact is defined in a broad manner. It comprises the child staying for a limited period of time with or meeting a parent or person other than a parent with whom he or she is not usually living, i.e. visits and any form of oral or written communication between the child and such person (Principle 3:26 (1)).

The Principles deal with contact with parents and other persons but make some distinctions. The closest link is between the child and the parents. Therefore these

\footnotetext{
${ }^{25)}$ Convention on Contact Concerning Children, 15 ${ }^{\text {th }}$ May 2003 (CETS No.192).

26) Art. 1 para. 2 (a) Council Regulation (EC) No. 2201/2003 of 27th November 2003 concerning jurisdiction and the recognition and enforcement of judgments in matrimonial matters and the matters of parental responsibility (Brussels II bis), Official Journal 2003 L 338/1.
} 
persons should have the right to obtain and maintain regular contact with each other (Principle 3:25 (1)). These rights exist vice versa. Certain persons other than a parent may also have a right of contact with the child. However, the Principles do make a distinction. Contact should be established between the child and his or her close relatives, i.e. grandparents and siblings (Principle 3:25 (2)). For a third group of persons the Principles follow a trend that there should be a more cautious approach. ${ }^{27}$ Contact may only be established between the child and a person with whom he or she has close personal relations (Principle 3:25 (3)). This may be the former partner of a parent. Just as under national laws, contact may be restricted, terminated or made subject to conditions by the competent authority if the best interests of the child so require (Principle 3:28). A separate principle is devoted to information to parents. In particular, the non-residential parent should have the right to be informed about matters concerning the personal situation of the child (Principle 3:29).

\subsection{Termination}

Chapter VI of the CEFL Principles deals briefly with the termination of parental responsibilities (Principle 3:30). Several situations involving such a termination are enumerated. It goes without saying that parental responsibilities should be terminated in the case of the child reaching majority (Principle 3:30 (1) (a)). The same is true where the child has died (Principle 3:30 (1) (d)). The Principles have also opted for a rule which is not known to every legal system but is widely accepted, i.e. that entering into a marriage or a registered partnership also terminates parental responsibilities (but does not exclude protective measures if necessary) ${ }^{28}$ (Principle 3:30 (1) (b)). Being adopted by someone else is another ground (Principle 3:30 (1) (c)). However, if a parent's partner adopts the child of the parent the parental responsibilities in relation to the other parent should be terminated (Principle 3:30 (2)). Stepchild adoption, which is criticised by some authors, ${ }^{29}$ is as such not dealt with in the CEFL Principles.

Principle 3:31 deals with the death of one or both parents. If the parents have joint parental responsibilities and one of them dies, the responsibilities should belong to the surviving parent (Principle 3:31 (1)). It is the common core that in these cases simply one of the parents remains responsible. ${ }^{30}$ However, if a parent having sole parental responsibilities dies, then these responsibilities should be attributed to the surviving parent or a third person upon a decision by the competent authority (Principle 3:31 (2)). On the death of both parents, of whom at least one parent had parental responsibilities, the competent authority should take protective measures in respect of the person and the property of the child (Principle 3:31 (3)).

\footnotetext{
27) Plötzgen [8], p. $110 \mathrm{ff}$.

${ }^{28)}$ Boele-Woelki/Braat/Curry-Sumner [2], p. $55 \mathrm{ff}$.

29) Schwenzer [9], p. 123.

${ }^{30)}$ Boele-Woelki/Braat/Curry-Sumner [2], p. $455 \mathrm{ff}$.
} 


\subsection{Discharge and restoration}

Chapter VII of the Principles deals with discharge and restoration of parental responsibilities. It is generally agreed that there must be a discharge of parental responsibilities if the child is in danger. Therefore the competent authority should discharge, wholly or in part, the holder of parental responsibilities where his or her behaviour or neglect poses a serious risk to the person or the property of the child (Principle 3:32). In the interest of the child there should be no formal restrictions to a request for the discharge of parental responsibilities. The discharge of parental responsibilities may be requested by any parent having parental responsibilities (Principle 3:33 (1) (a)). The child himself or herself and any institution protecting the interests of the child can also make such an application (Principle 3:33 (1) (b) (c)). However, if there is no request the competent authority may also order the discharge of parental responsibilities of its own motion (Principle 3:33 (2)). The discharge of parental responsibilities may not be permanent; a restoration of parental responsibilities is possible. Having regard to the best interests of the child, the competent authority may restore parental responsibilities if the circumstances that led to the discharge no longer exist (Principle $3: 34)$. It is also the common core that this regaining of previous rights may not endanger the child anew. ${ }^{31}$

\subsection{Procedure}

The CEFL Principles' final Chapter on procedure follows the traditional approach that all decisions on parental responsibilities should be taken by the competent authority, which can be either a judicial or an administrative body. However, the increasing importance of alternative dispute resolution, which is often still at an experimental stage but is being increasingly recognised by national laws, ${ }^{32}$ is also acknowledged by the Principles. In all disputes regarding parental responsibilities, alternative dispute resolution mechanisms should be available (Principle 3:36). In conformity with its basic approach that the autonomy of the child is to be respected (Principle 3:4) and according to the recognition of the child's right to be heard, Principle 3:37 also stresses that the child should be heard in the context of proceedings. The competent authority should generally hear the child in all proceedings concerning parental responsibilities. It is recognised, however, that there are situations where such a hearing could do more harm than good. However, this should remain an exception and if the authority decides not to hear the child it should give specific reasons for this in its decision. There is no uniform approach in the national systems as to whether the hearing of the child should take place directly before the competent authority (e.g. Germany ${ }^{33}$ ) or indirectly before a person or body appointed by the competent authority (e.g. England \& Wales ${ }^{34}$ ). The Principles prefer a direct hearing; the court should use the knowledge of experts but should form its own impression. However, the Principles also respect the situation where, under the national rules of procedure,

\footnotetext{
${ }^{31)}$ Boele-Woelki/Braat/Curry-Sumner [2], p. $707 \mathrm{ff}$.

${ }^{32)}$ Boele-Woelki/Braat/Curry-Sumner [2], p. $741 \mathrm{ff}$.

${ }^{33)}$ Dethloff [5], p. 322 f.; Boele-Woelki/Braat/Curry-Sumner [2], p. 791.

${ }^{34)}$ Boele-Woelki/Braat/Curry-Sumner [2], p. 790.
} 
there can only be an indirect hearing. The child should be heard in a manner which is appropriate to his or her age and maturity (Principle 3:37 (3)). No specific age limit is given.

\section{Some final reflections}

In most respects the CEFL Principles regarding Parental Responsibilities try to express what seems to be the modern common core of the international and European instruments and the legal systems under review. However, following a broad concept of parental responsibilities the Principles also developed a comprehensive and original set of rules based on respect for the rights of the child, non-discrimination and, as far as possible, on the self-determination of the parents and other holders of parental responsibilities. In their provisions on specific issues, the Principles opted for solutions which seem to be workable and ought to avoid unnecessary hardship and disputes. This factual approach to specific issues also tries to overcome the divide between conflicting civil and common law concepts. On the other hand, the CEFL Principles have to leave many details to national law because the background in other fields of family law, patrimonial law, civil procedure, administrative law and social security law is so different.

Whether national jurisdictions will adopt the solutions of the CEFL Principles in the long run cannot be predicted. This depends on political choices which cannot be influenced by the CEFL. In the future, however, national legislatures, when reforming their law on parental responsibilities, may make use of the CEFL's comparative materials and its suggestions as to how the law on parental responsibilities could be harmonised. In this respect the non-binding character of the CEFL Principles should be considered as a challenge and definitely not as a threat, in particular to those who argue that family law cannot be the subject of any unification or harmonisation due to cultural differences among European jurisdictions. However, in the field of parental responsibilities the differences among the European systems are already considerably less strong than in other fields of family law. Hence, CEFL's findings generally conclude that with regard to the great majority of the aspects compared, common solutions are applied. This does not come as a real surprise. The harmonisation of the law regarding parental responsibilities within Europe has gradually taken place through the many international and European instruments. Their very existence proves that harmonisation in this field is indeed possible. However, this harmonisation debate should not distract from the main task which is still to develop rules which serve most effectively the best interests of children. 


\section{Principles of European Family Law Regarding Parental Responsibilities}

\section{Preamble}

Recognising that, notwithstanding the existing diversities of national family law systems, there is nevertheless a growing convergence of laws;

Recognising that the free movement of persons within Europe is hindered by the remaining differences;

Desiring to contribute to common European values regarding the child's rights and welfare;

Desiring to contribute to the harmonisation of family law in Europe and to further facilitate the free movement of persons within Europe;

The Commission on European Family Law recommends the following Principles:

\section{Chapter I: Definitions}

\section{Principle 3:1 Concept of parental responsibilities}

Parental responsibilities are a collection of rights and duties aimed at promoting and safeguarding the welfare of the child. They encompass in particular:

(a) care, protection and education;

(b) maintenance of personal relationships;

(c) determination of residence;

(d) administration of property, and

(e) legalt representation.

\section{Principle 3:2 Holder of parental responsibilities}

(1) A holder of parental responsibilities is any person having the rights and duties listed in Principle 3:1 either in whole or in part.

(2) Subject to the following Principles, holders of parental responsibilities are:

(a)the child's parents, as well as

(b) persons other than the child's parents having parental responsibilities in addition to or instead of the parents.

\section{Chapter II: Rights of the child}

\section{Principle 3:3 Best interests of the child}

In all matters concerning parental responsibilities the best interests of the child should be the primary consideration.

\section{Principle 3:4 Autonomy of the child}

The child's autonomy should be respected in accordance with the developing ability and need of the child to act independently. 


\section{Principle 3:5 Non-discrimination of the child}

Children should not be discriminated on grounds such as sex, race, colour, language, religion, political or other opinion, national, ethnic or social origin, sexual orientation, disability, property, birth or other status, irrespective of whether these grounds refer to the child or to the holders of parental responsibilities.

\section{Principle 3:6 Child's right to be heard}

Having regard to the child's age and maturity, the child should have the right to be informed, consulted and to express his or her opinion in all matters concerning the child, with due weight given to the views expressed by him or her.

\section{Principle 3:7 Conflict of interests}

The interests of the child should be protected whenever they may be in conflict with the interests of the holders of parental responsibilities.

\section{Chapter III: Parental responsibilities of parents and third persons}

\section{Principle 3:8 Parents}

Parents, whose legal parentage has been established, should have parental responsibilities for the child.

\section{Principle 3:9 Third persons}

Parental responsibilities may in whole or in part also be attributed to a person other than a parent.

\section{Principle 3:10 Effect of dissolution and separation}

Parental responsibilities should neither be affected by the dissolution or annulment of the marriage or other formal relationship nor by the legal or factual separation between the parents.

\section{Chapter IV: Exercise of parental responsibilities}

\section{Section A: Parents}

\section{Principle 3:11 Joint exercise}

Parents having parental responsibilities should have an equal right and duty to exercise such responsibilities and whenever possible they should exercise them jointly.

\section{Principle 3:12 Daily matters, important and urgent decisions}

(1) Parents having joint parental responsibilities should have the right to act alone with respect to daily matters.

(2) Important decisions concerning matters such as education, medical treatment, the child's residence, or the administration of his or her property should be taken jointly. In urgent cases a parent should have the right to act alone. The other parent should be informed without undue delay. 


\section{Principle 3:13 Agreement on exercise}

(1) Subject to the best interests of the child, parents having joint parental responsibilities may agree on the exercise of parental responsibilities.

(2) The competent authority may scrutinize the agreement.

\section{Principle 3:14 Disagreement on exercise}

(1) Where parents having joint parental responsibilities cannot agree on an important matter they may apply to the competent authority.

(2) The competent authority should promote agreement between the parents.

(3) Where agreement cannot be reached the competent authority should divide the exercise of parental responsibilities between the parents or decide the dispute. Nigel: do we have to insert a comma after reached?

\section{Principle 3:15 Sole exercise upon agreement or decision}

Subject to the best interests of the child a parent may exercise parental responsibilities alone

(a) upon agreement between the parents according to Principle 3:13, or

(b) upon a decision of the competent authority.

\section{Principle 3:16 Sole exercise by one parent}

If only one parent has parental responsibilities he or she should exercise them alone.

\section{Section B: Third persons}

\section{Principle 3:17 Exercise in addition to or instead of the parents}

A person other than a parent may exercise some or all parental responsibilities in addition to or instead of the parents.

\section{Principle 3:18 Decisions in daily matters}

The parent's partner living with the child may take part in decisions with respect to daily matters unless the other parent having parental responsibilities objects.

\section{Chapter V: Content of parental responsibilities}

\section{Section A: The child's person and property}

\section{Principle 3:19 Care, protection and education}

(1) The holders of parental responsibilities should provide the child with care, protection and education in accordance with the child's distinctive character and developmental needs.

(2) The child should not be subjected to corporal punishment or any other humiliating treatment.

\section{Principle 3:20 Residence}

(1) If parental responsibilities are exercised jointly the holders of parental responsibilities who are living apart should agree upon with whom the child resides. 
(2) The child may reside on an alternate basis with the holders of parental responsibilities upon either an agreement approved by a competent authority or a decision by a competent authority. The competent authority should take into consideration factors such as:

(a) the age and opinion of the child;

(b) the ability and willingness of the holders of parental responsibilities to cooperate with each other in matters concerning the child, as well as their personal situation;

(c) the distance between the residences of the holders of the parental responsibilities and to the child's school.

\section{Principle 3:21 Relocation}

(1) If parental responsibilities are exercised jointly and one of the holders of parental responsibilities wishes to change the child's residence within or outside the jurisdiction, he or she should inform the other holder of parental responsibilities thereof in advance.

(2) If the other holder of parental responsibilities objects to the change of the child's residence, each of them may apply to the competent authority for a decision.

(3) The competent authority should take into consideration factors such as:

(a) the age and opinion of the child;

(b) the right of the child to maintain personal relationships with the other holders of parental responsibilities;

(c) the ability and willingness of the holders of parental responsibilities to cooperate with each other;

(d) the personal situation of the holders of personal responsibilities;

(e) the geographical distance and accessibility;

(f) the free movement of persons.

\section{Principle 3:22 Administration of the child's property}

(1) The holders of parental responsibilities should administer the child's property with due care and diligence in order to preserve and where possible increase the value of the property.

(2) In administering the child's property the holders of parental responsibilities should not make gifts unless the gifts are deemed to be made under a moral obligation.

(3) The income derived from the child's property which is not needed for the proper management of the property or for the maintenance and education of the child may, where necessary, be used for the needs of the family.

\section{Principle 3:23 Restrictions}

(1) The holders of parental responsibilities should not administer property acquired by a child through a testamentary disposition or a gift, if the testator or the donor so instructed.

(2) Similarly the earnings by the child should not be administered by the holders of parental responsibilities unless the child is not of sufficient age and maturity to decide himself or herself.

(3) Where transactions can have significant financial consequences for the child the authorisation of the competent authority should be necessary. 


\section{Principle 3:24 Legal representation}

(1) The holders of parental responsibilities should legally represent the child in matters concerning the child's person or property.

(2) Legal representation should not take place where there is a conflict of interest between the child and the holders of parental responsibilities.

(3) Having regard to the child's age and maturity, the child should have the right to self-representation in legal proceedings concerning himself or herself.

\section{Section B: Maintenance of personal relationships}

\section{Principle 3:25 Contact with parents and other persons}

(1) The child and the parents should have the right to obtain and maintain regular contact with each other.

(2) Contact should be established between the child and his or her close relatives.

(3) Contact may be established between the child and persons with whom the child has close personal relations.

\section{Principle 3:26 Content of contact}

(1) Contact comprises the child staying for a limited period of time with or meeting a parent or person other than a parent with whom he or she is not usually living; and any form of communication between the child and such person.

(2) Such contact should be in the best interests of the child.

\section{Principle 3:27 Agreement}

(1) Subject to the best interests of the child, the parents and the other persons identified under Principle 3:25(2) and (3) may agree on contact.

(2) The competent authority may scrutinize the agreement.

\section{Principle 3:28 Restrictions}

Contact may be restricted, terminated or made subject to conditions by the competent authority if the best interests of the child so require.

\section{Principle 3:29 Information to parents}

A parent should have the right to be informed about matters concerning the personal situation of the child.

\section{Chapter VI: Termination of parental responsibilities}

\section{Principle 3:30 Termination}

(1) Parental responsibilities should be terminated in the case of the child:

(a) reaching majority;

(b) entering into a marriage or registered partnership;

(c) being adopted;

(d) dying.

(2) If a parent's partner adopts the child of the parent the parental responsibilities in relation to the other parent should be terminated. 


\section{Principle 3:31 Death of the parents}

(1) If parents have joint parental responsibilities and one of them dies the parental responsibilities should belong to the surviving parent.

(2) If a parent having sole parental responsibilities dies, responsibilities should be attributed to the surviving parent or a third person upon a decision by the competent authority.

(3) On the death of both parents, of whom at least one parent had parental responsibilities, the competent authority should take protective measures in respect of the person and the property of the child.

\section{Chapter VII: Discharge and restoration of parental responsibilities}

\section{Principle 3:32 Discharge of parental responsibilities}

The competent authority should discharge the holder of parental responsibilities, wholly or in part, where his or her behaviour or neglect causes a serious risk to the person or the property of the child

\section{Principle 3:33 Request for discharge of parental responsibilities}

(1) The discharge of parental responsibilities may be requested by:

(a) any parent having parental responsibilities;

(b) the child, and

(c) any institution protecting the interests of the child.

(2) The competent authority may also order the discharge of parental responsibilities of its own motion.

\section{Principle 3:34 Restoration of parental responsibilities}

Having regard to the best interest $\underline{s}$ of the child, the competent authority may restore parental responsibilities if the circumstances that led to the discharge no longer exist.

\section{Chapter VIII: Procedure}

\section{Principle 3:35 Competent authority}

(1) All decisions on parental responsibilities should be taken by the competent authority which can either be a judicial or an administrative body.

(2) Where necessary, the competent authority should appoint any suitable person or body to investigate the child's circumstances.

\section{Principle 3:36 Alternative dispute resolution}

In all disputes regarding parental responsibilities alternative dispute resolution mechanisms should be available.

\section{Principle 3:37 Hearing of the child}

(1) Subject to Principle 3:6, the competent authority should hear the child in all proceedings concerning parental responsibilities but if it decides not to hear the child it should give specific reasons. 
(2) The hearing of the child should take place either directly before the competent authority or indirectly before a person or body appointed by the competent authority.

(3) The child should be heard in a manner appropriate to his or her age and maturity.

\section{Principle 3:38 Appointment of a special representative for the child}

In proceedings concerning parental responsibilities in which there could either be a serious conflict of interests between the child and the holders of parental responsibilities or in which the welfare of the child is otherwise at risk, the competent authority should appoint a special representative for the child.

\section{Principle 3:39 Enforcement}

(1) Failing voluntary compliance, a decision by the competent authority and an enforceable agreement concerning parental responsibilities should be enforced without delay.

(2) Enforcement should not take place if it is manifestly contrary to the best interests of the child.

\section{References}

1. Boele-Woelki, K.: The Working Method of the Commission on European Family Law, in: BoeleWoelki, K. (ed.) Common Core and Better Law in European Family Law, European Family Law Series No. 10, 15-38 (2005)

2. Boele-Woelki, K., Braat, B., Curry-Sumner, I. (eds.): European Family Law in Action, Volume III: Parental Responsibilities, European Family Law Series No. 9 (2005)

3. Boele-Woelki, K., Ferrand, F., González Beilfuss, C., Jänterä-Jareborg, M., Lowe, N., Martiny, D., Pintens, W.: Principles of European Family Law Regarding Divorce and Maintenance Between Former Spouses, European Family Law Series No. 7 (2004)

4. Boele-Woelki, K., Ferrand, F., González Beilfuss, C., Jänterä-Jareborg, M., Lowe, N., Martiny, D., Pintens, W.: Principles of European Family Law Regarding Parental Responsibilities, European Family Law Series No. 16 (2007)

5. Dethloff, N.: Parental Rights and Responsibilities in Germany, Family Law Quarterly 39, 315 (2005)

6. Meeusen, J., Pertegás, M., Straetmans, G., Swennen, F.: General Report, Rapport Général, in: Meeusen, J., Pertegás, M., Straetmans, G., Swennen, F. (eds.), International Family Law for the European Union, 1-23, 25-48 (2007)

7. Patti, S.: Die neue italienische Regelung über das gemeinsame Sorgerecht, FamRZ, 1321 (2006)

8. Plötzgen, S.: Das Umgangsrecht von „Nicht-Eltern“ - Ein Vergleich des deutschen Rechts mit den umgangsrechtlichen Regelungen in England und in der Schweiz, (2005)

9. Schwenzer, I.: Model Family Code, European Family Law Series No. 12 (2006)

10. Stoljar, S. J.: Children, Parents and Guardians, International Encyclopedia of Comparative Law vol. 4 Ch. 7 (1973) 